\title{
The effect of a low-protein diet and a cold environment on calorie intake and body composition in the rat
}

\author{
By P. SCHMIDT* AND ELSIE M. WIDDOWSON \\ Medical Research Council Department of Experimental Medicine, \\ University of Cambridge
}

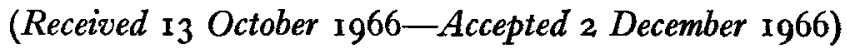

\begin{abstract}
I. Rats ro weeks old were fed for 9 weeks either on a stock diet containing $17 \%$ protein, or on a low-protein diet prepared from the stock diet with added glucose, minerals and vitamins. Half the animals on each diet were kept at room temperature $\left(2 \mathrm{I}^{\circ}\right)$ and half in a cold environment $\left(5^{\circ}\right)$.

2. The calorie intake of the animals kept at $5^{\circ}$ on both diets was $60-70 \%$ higher than that of the corresponding group at $21^{\circ}$. The animals on the stock diet and kept at $5^{\circ}$ gained weight but not so much as those on the same diet at $21^{\circ}$. The animals kept on the low-protein diet at $21^{\circ}$ lost weight, while those on the same diet at $5^{\circ}$ lost only a little weight initially and none thereafter.

3. On both types of diet the liver, kidneys and gastro-intestinal tract weighed more per $100 \mathrm{~g}$ body-weight in animals kept in the colder of the two environments; the small intestine was conspicuous in this respect.

4. The weight of the fur was greater, and the weight of the skin less per $100 \mathrm{~g}$ body-weight at $5^{\circ}$ than at $21^{\circ}$.

5. The animals on the stock diet at $21^{\circ}$ had most fat in their bodies, both in absolute terms and per $100 \mathrm{~g}$ body-weight. There were no significant differences between the other three groups.

6. The skin of the animals kept at $5^{\circ}$ had a significantly higher collagen to $\mathrm{N}$ ratio than the skin of those having the same diet at $21^{\circ}$.
\end{abstract}

Exposure to cold $\left(5^{\circ}\right)$ increases the calorie intake of the rat having a normal diet by 60-90\% (Young \& Cook, 1955; Andik \& Donhoffer, 1957). It also increases the calorie intake of the rat having a low-protein diet, and Andik, Donhoffer, Farkas \& Schmidt (1963) showed that, whereas young albino rats kept at room temperature on a diet containing $4.3 \%$ protein died within 6 weeks, others kept in a cold environment $\left(5^{\circ}\right)$ ate sufficient food to provide them with enough protein so that they survived and gained weight. Slightly older animals of another strain, having a low-protein diet different in composition from the original one, have now been studied to see whether this important effect could be reproduced at will, or whether it could be observed only under the special conditions of the original study. Widdowson \& McCance (1957), Stanier (1957), Cabak, Dickerson \& Widdowson (1963) and others have investigated the effect of a low-protein diet on the composition of the bodies of rats, and Emery, Emery \& Schwabe (1940), Heroux \& Gridgeman (1958), Heroux (196r, 1963) and Barnett \& Widdowson (1965) have made observations on the effect of a cold environment on body composition. The present study has included measurements of body composition to investigate the combined effect on it of the two stresses, a low-protein diet and a low environmental temperature.

* Present address: Institute of Pathophysiology, University Medical School, Pécs, Hungary. 
Fifty-five male black and white hooded rats, originally obtained from the Lister strain, were used for these experiments. The preliminary period of the experiment started when the animals were 9-Io weeks old and lasted for 8-10 days. During that time they were kept in the animal house at a temperature of $21^{\circ}$ and fed on a pelleted diet (diet $4 \mathrm{I}$ B, Bruce, 1963) in unlimited amounts. The food intake was measured daily. After this period the animals were divided into five groups. Ten animals were killed as 'starting controls' and their body composition was measured. Twelve animals remained at an environmental temperature of $21^{\circ}$ and continued to eat diet $4^{\mathrm{I}} \mathrm{B}$. Eleven animals also had this diet, but were put in a cold environment $\left(5^{\circ}\right)$. Eleven animals were kept in a warm environment $\left(21^{\circ}\right)$ and received the low-protein diet described below and eleven animals were placed in the cold environment $\left(5^{\circ}\right)$ and were given the low-protein diet. All the animals were housed in individual cages and food and water were supplied ad lib. A small amount of sawdust was placed on the bottom of the cages, but there was not enough of this to allow the animals to make nests in the cold.

The main experiment lasted for 9 weeks, and during this time food intake was

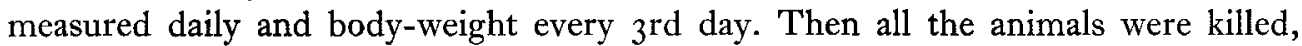
dissected and analysed as described later.

\section{Composition of the diets}

Diet $4 \mathrm{I}$ B contained about $17 \%$ protein and provided $3.4 \mathrm{kcal} / \mathrm{g}$. The low-protein diet was made up by mixing powdered diet $4 \mathrm{I}$ B with enough glucose to produce a mixture containing $4.3 \%$ protein and providing $3.7 \mathrm{kcal} / \mathrm{g}$. To $1000 \mathrm{~g}$ of this mixture were added: $\mathrm{CaCO}_{3} 20 \mathrm{~g}, \mathrm{NaCl} 20 \mathrm{~g}$, iron citrate $4 \mathrm{~g}, \mathrm{KI} 0.16 \mathrm{~g}$, and Vitamin $\mathrm{B}$ Complex Powder (Crookes Laboratories Ltd) $3 \mathrm{~g}$.

\section{Measurement of food intake}

The stock diet $4 \mathrm{I} B$ and the low-protein diet, both in powdered form, were put into a tared glass jar and weighed. The powder was mixed with sufficient water to make a thick paste, and the jar fastened to the side of the cage with wire. Each $24 \mathrm{~h}$ the jar was removed and placed in an oven at $100^{\circ}$ for $24 \mathrm{~h}$ and then weighed so that the weight of the dry food uneaten could be measured. In calculating the amount of food eaten a correction was applied for the moisture in the stored powdered food.

\section{Killing and dissection of the animals}

The rats were killed with ether. The liver and kidneys were removed and weighed, and the whole gastro-intestinal tract was weighed before and after being emptied, and then the stomach, small intestine and large intestine were separated and the empty organs weighed. The skin was removed from the carcass, the fur shaved off it, and each separately analysed. Finally the organs other than the skin and fur were returned to the carcass. 


\section{Chemical analysis}

Carcass and skin. Water was determined by drying the material at $103^{\circ}$ until constant in weight. Then the fat was removed by repeated extractions with light petroleum at room temperature and the amount of fat was taken to be the difference in weight before and after the extractions. The fat-free dry residues were then ground in a Culatti hammer mill.

The nitrogen was determined on portions of the powder by the micro-Kjeldahl method after digestion with conc. $\mathrm{H}_{2} \mathrm{SO}_{4}$ as described by Dickerson \& Widdowson (I960). Collagen was determined by a modified Neuman \& Logan (1950) method as described by Dickerson ( 1962 ). Calcium in the carcass was determined on samples taken from the acid hydrolysate prepared for the collagen determination by the Clark and Collip modification of the Kramer \& Tisdall method (Hawk, Oser \& Summerson, 1954).

Fur. The fur was dried at $103^{\circ}$ until constant in weight and $\mathrm{N}$ was determined on the dry material by the method used for carcass and skin.

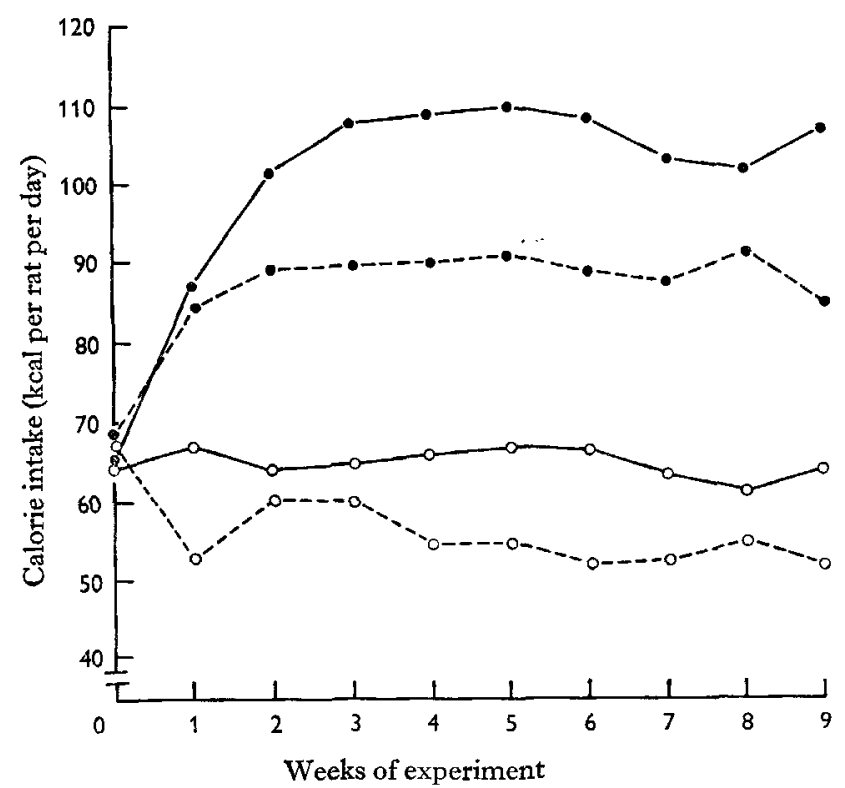

Fig. I. Calorie intakes, during each week of the experiment, of rats kept at an environmental temperature of $21^{\circ}$ or $5^{\circ}$ and given a stock or a low-protein diet. $0-0$, stock diet, warm; -1 , stock diet, cold; $\mathrm{O}_{--\mathrm{O}}$, low-protein diet, warm; $\ldots$, low-protein diet, cold.

\section{RESULTS}

\section{Food intakes}

Fig. I shows that the calorie intake of the animals having the stock diet and kept at $2 \mathrm{I}^{\circ}$ remained fairly constant during the 9 weeks of the experiment. The calorie intake of the animals given the stock diet and kept at $5^{\circ}$ rose significantly in the Ist week $(P<0.001)$ and became stable at a high level from the 3 rd week. The animals kept in the cold ate $60-70 \%$ more of the stock diet than those kept at room temperature. 
The calorie intake of the 'low-protein' animals at $2 \mathrm{I}^{\circ}$ fell during the Ist week they were given this diet and remained lower than that of the rats having the stock diet in the warm environment. The intake of the 'low-protein' animals at $5^{\circ}$ was significantly higher than that of the group on this diet at $2 \mathrm{I}^{\circ}$ after $\mathrm{I}$ week, and these animals ate significantly more than they themselves had eaten during the preliminary period $(P<0.001$ in both instances).

The animals having the low-protein diet and kept at $5^{\circ}$ ate $60-70 \%$ more food than those having the same diet at $21^{\circ}$, so that the effect of a cold environment on the calorie intake was the same whichever the amount of protein in the diet.

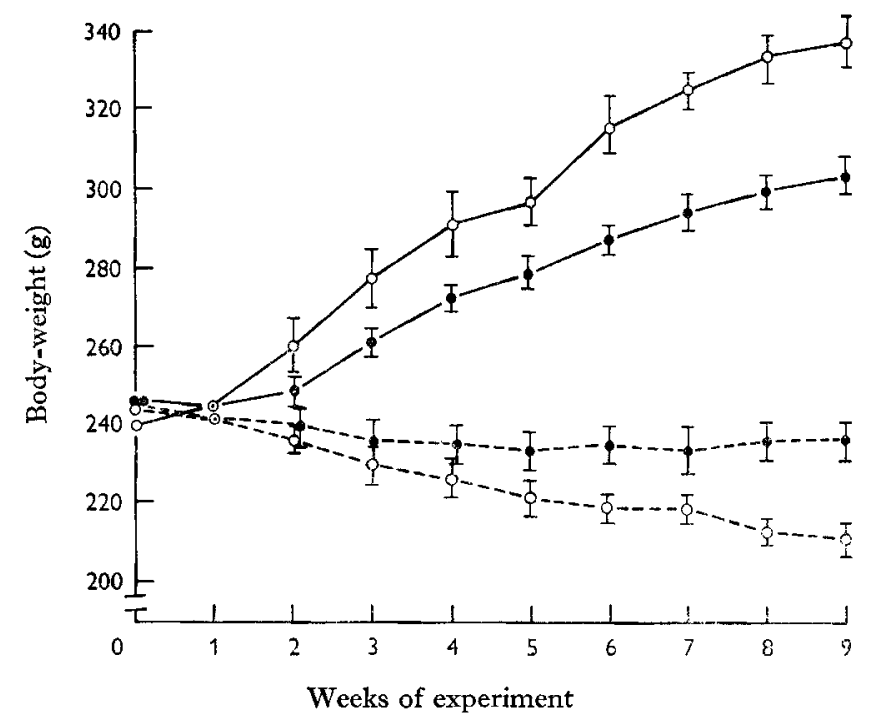

Fig. 2. Body-weights of rats kept at an environmental temperature of $2 \mathrm{I}^{\circ}$ or $5^{\circ}$ and given a stock or a low-protein diet. $\mathrm{O}-\mathrm{O}$, stock diet, warm; $-\longrightarrow$, stock diet, cold; $\mathrm{O}--\mathrm{O}$, low-protein, diet, warm; ---@, low-protein diet, cold. Mean values with their standard errors are shown.

\section{Body-weights}

Fig. 2 shows the body-weights. The animals eating the stock diet at $2 \mathrm{I}^{\circ}$ grew normally and gained $40 \%$ of their mean initial weight in 9 weeks. Those eating the stock diet and kept at $5^{\circ}$ also gained weight, but less than those kept at $2 \mathrm{I}^{\circ}$, and their mean weight after 9 weeks was only $23 \%$ higher than it was at the beginning. One rat having the stock diet and kept at $2 \mathrm{I}^{\circ}$ died during the experiment but none died that had the stock diet and were kept at $5^{\circ}$.

The animals having the low-protein diet at $2 \mathrm{I}^{\circ}$ lost weight, and the mean loss was $13 \%$ of the initial weight. Those having the stock diet and kept at $5^{\circ}$ lost weight for the first 3 weeks only, and at the end their mean weight was only $4.4 \%$ less than it was at the beginning. The difference between the mean weights of the two groups of 'low-protein' animals at the end of the experiment was statistically significant $(P<0.001)$. Two of the 'low-protein' animals kept at $5^{\circ}$, but none of those kept at $2 \mathrm{r}^{\circ}$, died. 


\section{Weights of organs and tissues}

Table I shows the absolute weights of some of the organs and tissues of the animals at the beginning and end of the experiment, and Table 2 gives the weights expressed as a percentage of the body-weight.

Table I. Absolute weights ( $g$ ) of organs and tissues of rats kept at an environmental temperature of $2 \mathrm{I}^{\circ}$ or $5^{\circ}$ and given a stock or a low-protein diet

(Mean values with their standard errors)

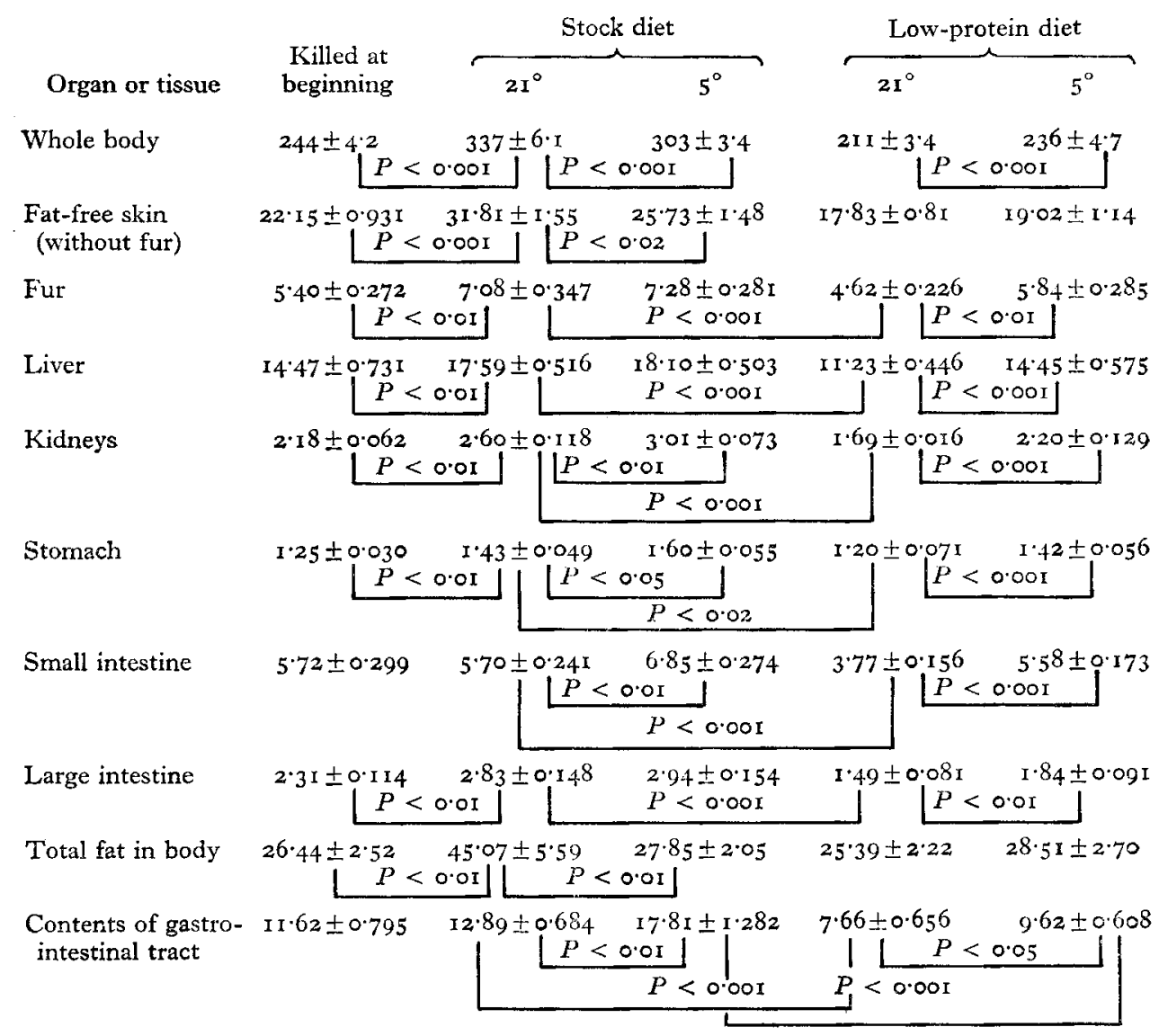

In spite of their smaller body-weight the animals eating the stock diet at $5^{\circ}$ had more fur, and heavier livers, kidneys and gastro-intestinal tracts than rats having the same diet and kept at $21^{\circ}$. The differences for kidneys, stomach and small intestine were statistically significant. On the other hand, animals eating the stock diet at $2 \mathrm{I}^{\circ}$ had heavier skins and more fat than the corresponding animals at $5^{\circ}$. The animals in this group were in fact the only ones that deposited any significant amount of fat in their bodies over the 9 weeks of the experiment.

The animals that had the low-protein diet and were kept at $5^{\circ}$ were heavier and had 
Table 2. Weights of organs and tissues, as percentage of fat-free body-weight, of rats kept at an environmental temperature of $2 \mathrm{I}^{\circ}$ or $5^{\circ}$ and given a stock or a low-protein diet

(Mean values with their standard errors)

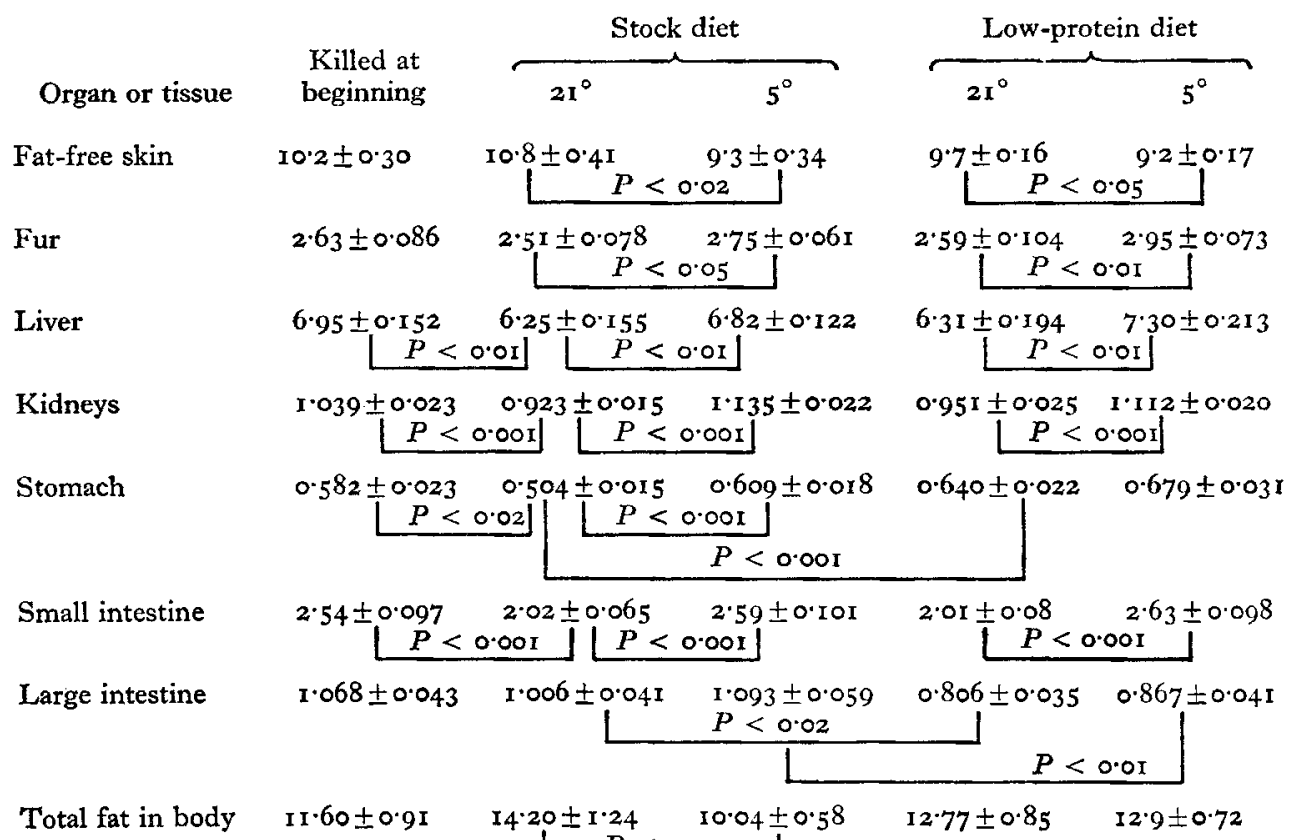

Table 3. Chemical composition ( $\mathrm{g} / \mathrm{1} 00$ fresh weight) of the fat-free bodies of rats kept at an environmental temperature of $21^{\circ}$ or $5^{\circ}$ and given a stock or a low-protein diet

(Mean values with their standard errors)

\begin{tabular}{|c|c|c|c|c|c|}
\hline & \multirow{2}{*}{$\begin{array}{l}\text { Killed at } \\
\text { beginning }\end{array}$} & \multicolumn{2}{|c|}{ Stock diet } & \multicolumn{2}{|c|}{ Low-protein diet } \\
\hline & & $21^{\circ}$ & $5^{\circ}$ & $21^{\circ}$ & $5^{\circ}$ \\
\hline $\begin{array}{c}\text { Fat-free body- } \\
\text { weight }(\mathrm{g})\end{array}$ & $\begin{array}{r}218 \pm 3.7 \\
P\end{array}$ & $292 \pm 4.2$ & $275 \pm 3 \cdot 1$ & $186 \pm 4^{\circ} \circ P$ & $207 \pm 4.2$ \\
\hline Water (g/100 g) & $\begin{array}{l}70.6 \pm 0.11 \\
P\end{array}$ & $\begin{array}{l}69.0 \pm 0.59 \\
001\end{array}$ & $68.9 \pm 0.56$ & $69 \cdot 6 \pm 0 \cdot 16$ & $69.4 \pm 0.2 I$ \\
\hline Total N (g/100g) & $3.25 \pm 0.110$ & $3.40 \pm 0.118$ & $3.28 \pm 0.092$ & $3.24 \pm 0.087$ & $3.35 \pm 0.125$ \\
\hline Collagen $(\mathrm{g} / 100 \mathrm{~g})$ & $\begin{array}{r}4.45 \pm 0.25 \\
\square \\
\end{array}$ & $\begin{array}{l}5.30 \pm 0.31 \\
.05 !\end{array}$ & $4.80 \pm 0.17$ & $02]^{5.47 \pm 0.18}$ & $5.22 \pm 0.26$ \\
\hline $\begin{array}{l}\text { Non-collagen } N \\
(\mathrm{~g} / 100 \mathrm{~g})\end{array}$ & $2.45 \pm 0.09$ & $2.55 \pm 0.12$ & $2 \cdot 41 \pm 0.09$ & $2 \cdot 26 \pm 0 \cdot I I$ & $2.41 \pm 0.12$ \\
\hline Calcium $(\mathrm{g} / \mathrm{1} 00 \mathrm{~g})$ & $0.95 \pm 0.042$ & $\left..05\right|^{.09 \pm 0.047}$ & $\begin{array}{c}1.08 \pm 0.033 \\
P<0.02\end{array}$ & $\stackrel{1.28}{1} \pm 0.05$ & $01]^{x \cdot 00 \pm 0.055}$ \\
\hline
\end{tabular}


more fur and larger organs than those having the same diet and kept at $2 \mathrm{I}^{\circ}$. However, liver, kidneys and digestive tract all formed a greater percentage of the body-weight at $5^{\circ}$ than at $21^{\circ}$ (Table 2), and the differences for kidneys and small intestine were highly significant. The relative weight of the skin was significantly less at $5^{\circ}$ than at $21^{\circ}$ on the low-protein as well as on the stock diet. The animals eating the low-protein diet at both temperatures had heavier stomachs and lighter large intestines per $100 \mathrm{~g}$ body-weight than the stock animals. The low weight of the large intestine per $100 \mathrm{~g}$ body-weight in the 'ow-protein' rats was presumably due to the smaller amount of unavailable carbohydrate in their diet; the absolute weight of material in the digestive tract of the 'low-protein' animals at death was little more than half that in those having the stock diet (Table I).

Table 4. Distribution of nitrogen in the bodies of rats kept at an environmental temperature of $21^{\circ}$ or $5^{\circ}$ and given a stock or a low-protein diet

(Mean values with their standard errors)

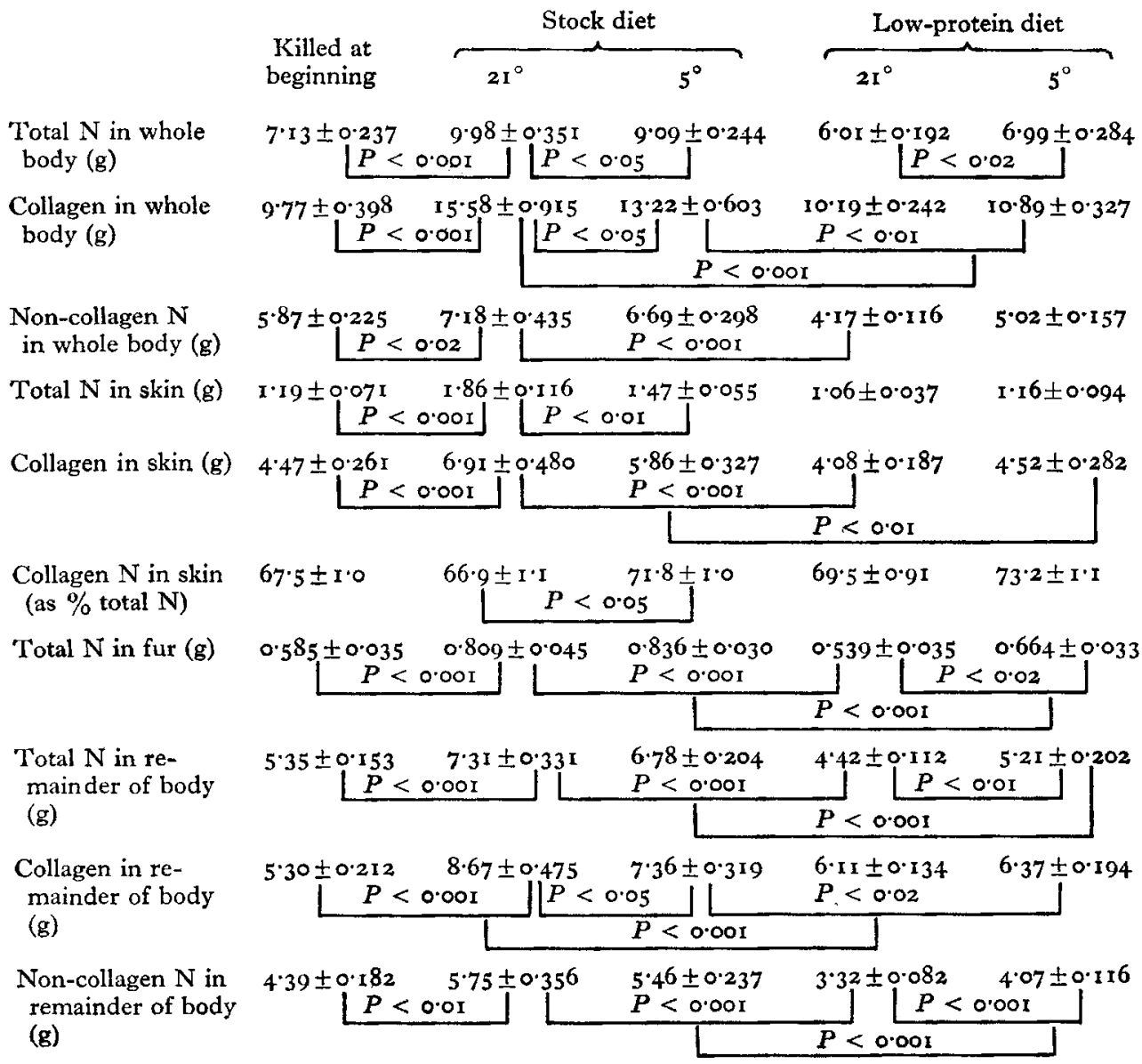




\section{Composition of the whole body}

There were no significant differences between the percentages of water or total $\mathrm{N}$ in the fat-free body tissue in any of the experimental groups (Table 3). The slightly higher mean values for water in the animals killed at the beginning of the experiment and the lower value for collagen can be explained by the younger age of the animals.

The higher concentration of $\mathrm{Ca}$ in the bodies of the small rats having the lowprotein diet at $2 \mathrm{I}^{\circ}$ is a reflection of the fact that the skeleton did not participate significantly in the loss of body-weight, and it therefore came to form a larger proportion of the body-weight than it did in the heavier animals in the other three groups.

Table 4 gives some information about the total amounts of $\mathrm{N}$ and of collagen in the body as a whole, and in the skin and fur. The animals having the low-protein diet at $2 \mathrm{I}^{\circ}$ lost $15 \%$ of their body $\mathrm{N}$ over the 9 weeks of the experiment, whereas those on the stock diet at both temperatures gained $\mathrm{N}$. Those having the low-protein diet at $5^{\circ}$ neither gained nor lost significant amounts. The loss of $\mathrm{N}$ from the 'low-protein' animals at $2 \mathrm{I}^{\circ}$ was largely non-collagen $\mathrm{N}$ and most of it came from the parts of the body other than the skin and fur. The amount of collagen in the body in fact increased. The skin of these animals lost about $10 \%$ of its $\mathrm{N}$, and this came both from the collagen and non-collagen fractions.

\section{DISCUSSION}

The daily calorie intake of the rats is in good agreement with previous experimental findings (Andik, Bank, Móring \& Szegvári, 1954) and the increase of $60-70 \%$ in calorie intake in the colder environment is also in accordance with them (Andik et al. 1963). At both environmental temperatures the animals having the low-protein diet took fewer calories than those having the stock diet, but the effect of the cold environment was to counteract the loss of appetite on the low-protein diet, so that the rats having the low-protein diet and kept at $5^{\circ}$ ate considerably more than those having the stock diet at $2 \mathrm{I}^{\circ}$.

The animals having the stock diet at $5^{\circ}$ did not eat quite enough extra food to enable them to grow at the same rate as animals having the stock diet at $2 \mathrm{I}^{\circ}$, which agrees with the findings of Heroux (1961, 1963 ). The animals having the low-protein diet and kept at $2 \mathrm{I}^{\circ}$ lost weight but, in contrast to the findings of Andik et al. (1963), none of them died during the 9 weeks of the experiment. In spite of their increase in calorie intake, those having the low-protein diet and kept at $5^{\circ}$ did not gain weight, in fact they lost a little, so the results of this experiment differ in degree, though not in principle, from the earlier ones of Andik et al. (1963). The difference may have been due to the larger size of the rats at the beginning of the present study, the use of a different strain and, perhaps most important, the different source of the protein.

The effect of a cold environment on the weights of the organs as found in the present study agrees with previous observations of Emery et al. (1940), Heroux \& Gridgeman (1958) and Barnett \& Widdowson (1965). The weights of the gastrointestinal tract, liver, and kidneys, which formed a higher percentage of the bodyweight at $5^{\circ}$ than at $21^{\circ}$, are all influenced by food intake, and their greater weight can 
probably be regarded as a direct consequence of the higher food intake at the former temperature.

In contrast to the findings of Heroux ( 1963 ), there was a significant increase in the amount of fur after a comparatively short period in the cold. Barnett, Coleman \& Manly (1959) found that mice kept and bred for many generations at $-3^{\circ}$ had relatively more fur than those kept and bred at $21^{\circ}$, but they made no measurements over short periods. Barnett et al. (I959) found that mice bred at $-3^{\circ}$ had a significantly smaller weight of skin per $100 \mathrm{~g}$ body-weight than those bred at $2 \mathrm{I}^{\circ}$, and Barnett \& Widdowson (1965) have recently confirmed this. We have made the same observation in our rats which were kept at $5^{\circ}$ for 9 weeks, so this reduction in the contribution of the weight of the skin to the weight of the body takes place over a comparatively short period of time. It is difficult to explain this; the only difference we observed in the composition of skin at $5^{\circ}$ and at $2 \mathrm{I}^{\circ}$ was that collagen $\mathrm{N}$ formed a higher percentage of the total $\mathrm{N}$ in the latter group. A reduction in the contribution of the cellular part is probably responsible for the smaller weight in the colder environment.

Widdowson \& McCance (I957), Wallace, Weil \& Taylor (1958), and Čabak et al. (1963) did not find that the administration of a low-protein diet to growing rats kept at room temperature made any difference to the percentage of $\mathrm{N}$ in the fat-free body tissue. In the present experiments also there was no significant difference between the percentage of $\mathrm{N}$ in the fat-free bodies of the animals undergoing any of the four experimental treatments. However, changes undoubtedly take place in the distribution of $\mathrm{N}$ in the body in response to a low-protein diet and in response to cold, and it is doubtful if the percentage of total $\mathrm{N}$ in the body is of any biological significance.

We are grateful to Professor R. A. McCance for his continued interest and encouragement in this investigation. One of us (P. S.) is indebted to the British Council for a personal grant.

\section{REFERENCES}

Andik, I., Bank, J., Móring, I. \& Szegvári, G. (1954). Acta physiol. hung. 5, 457.

Andik, I. \& Donhoffer, Sz. (1957). Pfiugers Arch. ges. Physiol. 264, 585.

Andik, I., Donhoffer, Sz., Farkas, M. \& Schmidt, P. (1963). Br. F. Nutr. 17, 257.

Barnett, S. A., Coleman, E. M. \& Manly, B. M. (г959). Q. Il exp. Physiol. 44, 43 .

Barnett, S. A. \& Widdowson, E. M. (1965). Proc. R. Soc. B 162, 502.

Bruce, H. M. (1963). F. Reprod. Fert. 6, 221.

Cabak, V., Dickerson, J. W. T. \& Widdowson, E. M. (1963). Br. F. Nutr. I7, 601.

Dickerson, J. W. T. (I962). Biochem. $7.82,47$.

Dickerson, J. W. T. \& Widdowson, E. M. (1960). Biochem. F. 74, 247.

Emery, F. E., Emery, L. M. \& Schwabe, E. L. (1940). Growth 4, I7.

Hawk, P. B., Oser, B. L. \& Summerson, W. H. (1954). Practical Physiological Chemistry, 13th ed., p. 589. London: J. and A. Churchill Ltd.

Heroux, O. ( $196 \mathrm{I}$ ). Revue can. Biol. 20, 55.

Heroux, O. (1963). Fedn Proc. Fedn Am. Socs exp. Biol. 22, 789.

Heroux, O. \& Gridgeman, N. T. (1958). Can. F. Biochem. Physiol. 36, 209.

Neuman, R. E. \& Logan, M. A. (1950). F. biol. Chem. r84, 299.

Stanier, M. W. (1957). Br. F. Nutr. xr, 206.

Wallace, W. M., Weil, W. B. \& Taylor, A. (1958). Ciba Fdn Colloq. Ageing 4, I 16.

Widdowson, E. M. \& McCance, R. A. (r957). Br. F. Nutr. rI, 198.

Young, D. R. \& Cook, S. F. (1955). Am. F. Physiol. 181, 72. 